\title{
Monsterdelfinen fra Trias - mød Verdens største marine krybdyr
}

\author{
Af geolog Morten L. \\ Hjuler, GeologiskNyt

\section{Shonisaurus} \\ sikanniensis må \\ have mindet om \\ en overvægtig \\ delfin med sin \\ lange snude og en \\ betragtelig hæn- \\ gebug, men trods \\ en imponerende \\ kropslængde på \\ over $20 \mathrm{~m}$ var den \\ muligvis en frede- \\ lig kæmpe.
}

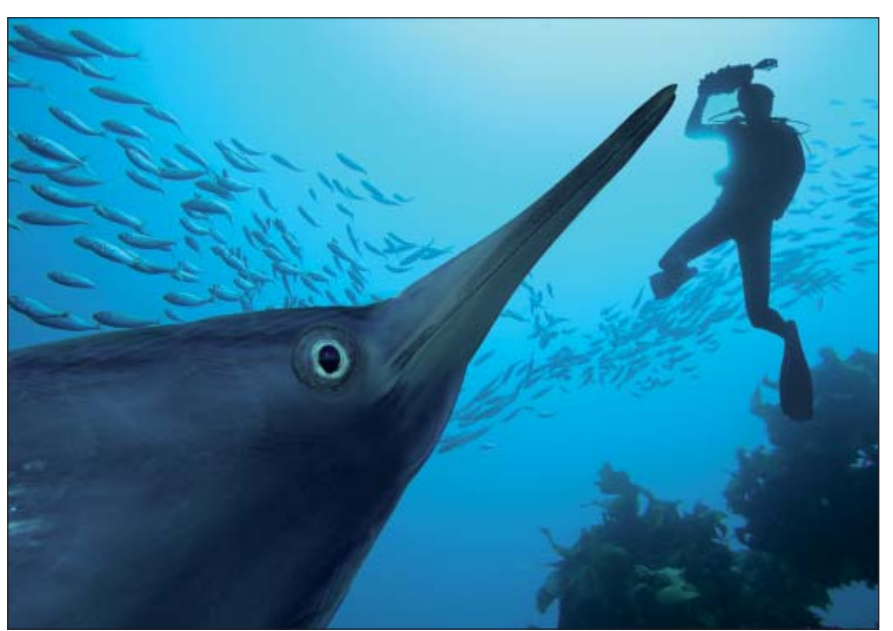

En dykker får sig en forskrcekkelse, da en nysgerrig Shonisaurus sikanniensis lige skal se, hvad han er for en underlig fisk! ("Foto": Forfatteren)
I BBC's flotte, men måske lige lovligt fabulerende computeranimerede naturserie "Walking with Dinosaurs" optræder den jurassiske pliosaur, Liopleurodon, et marint kødædende monster, som ifølge serien opnåede en frygtindgydende længde på $25 \mathrm{~m}$. Går man denne skræmmende farsfabrik efter i sømmene, viser det sig, at den i virkeligheden kun blev sølle 10-12 m. Et hårdt slag for os, som elsker gyset ved tanken om de monstrøse uhyrligheder, som pjaskede eller slentrede rundt i fortiden.

Der er dog ingen grund til fortvivlelse, for dybt inde i det canadiske vildnis dukkede i 1991 et nyt marint reptil frem fra sin kolde kalkstensgrav - og denne gang er der ingen tvivl om længden...

\section{Den umulige opgave}

Det begyndte i 1991med arkæologen, Keary Walde, som på en vandretur i den canadiske provins British Columbias dybe skove faldt over de fossile rester af et enormt dyr. Han rapporterede sit fund til det velkendte Royal Tyrrell Museum i Alberta, hvor Dr. Elizabeth Nicholls, en autoritet inden for studiet af forhistoriske, marine reptiler, straks fattede interesse for fundet.

Hun besøgte lokaliteten og kunne ved selvsyn konstatere, at der var tale om den største såkaldte ichthyosaur, hun nogensinde havde set. Ichthyosaurerne var delfinlignende krybdyr, som huserede i Trias-, Jura- og Kridt-havene; med en strømlinet krop og kraftige finner var de særdeles veltilpasset livet som jægere i havet.

Det var fra starten klart, at bjærgningen af denne ichthyosaur ville blive en næsten håbløs opgave. Fossilet lå indkapslet i kalksten umiddelbart op til Sikanni Chief-floden i uvejsomt terræn med tæt skov, og nærmeste vej var $2 \mathrm{~km}$ væk. Floden går ofte over sine breder, og skelettet var oversvømmet store dele af året. Udgravning var derfor kun mulig få uger hvert år, og al fragt af udstyr og fossiler til og fra lokaliteten måtte foregå med helikopter. Men forhindringerne blev overvundet, og efter tre års udgrav- ning blev den sidste skeletdel fløjet ud i 2000

De følgende år blev ichthyosaurens skelet præpareret frem fra de mange bjærgede kalkstensblokke, og i 2004 blev det 220 millioner år gamle sentriassiske vidunder præsenteret: Shonisaurus sikanniensis.

\section{En triassisk kæmpe}

Shonisaurus sikanniensis var $21 \mathrm{~m}$ lang og dermed hele $6 \mathrm{~m}$ længere end det hidtil længste marine krybdyr (også en Shonisaurus). Kraniet alene måler 2,4 $\mathrm{m}$ i længden og 1,8 $\mathrm{m}$ i bredden.

Det er interessant, at $S$. sikanniensis er tandløs, et forhold som også gør sig gældende hos andre Shonisaurus-arter, mens yngre Shonisaurus-individer vides at besidde tænder. Man spekulerer nu i, at dyrene tabte tænderne, i takt med at de blev voksne, og i stedet udviklede bardelignende filtersystemer, som dem vi kender fra nutidens hvaler; eller måske udviklede de en slags næb til at fastholde byttedyr.

Shonisaurus minder på flere punkter om delfiner. Begge er kendetegnet ved en strømlinet krop, perfekt tilpasset livet i vandet, og en lang snude tæt besat med tænder (dog kun unge Shonisaurus-individer som nævnt). Men hvor delfiner kun besidder luffer foran, er Shonisaurus udstyret med disse både for og bag, og Shonisaurus' hale er lodret, hvor delfinens er vandret.

Traditionelt er Shonisaurus afbildet med "hængebug", hvilket forlener dyret med et lidt plumpt udseende. Nyere undersøgelser sår dog tvivl om, hvor veludviklet denne hængebug var.

\section{Ingen større?}

Lige nu er Shonisaurus sikanniensis det største marine krybdyr, vi kender til med sikkerhed, men meget tyder på, at ichthyosaurerne udviklede betydeligt større individer. Enkeltstående fund af enorme ryghvirvler indikerer, at nogle former kunne blive over $25 \mathrm{~m}$ lange. Men så længe disse indikationer ikke understøttes af tilstrækkeligt fossilmateriale, forbliver de spekulationer. 